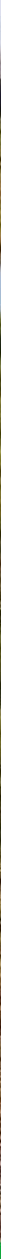

\title{
Vernatting Groene Hart: kostprijs melk en $\mathrm{CO}_{2}$-prijs
}





\section{Vernatting Groene Hart: kostprijs melk en $\mathrm{CO}_{2}$-prijs}

C.H.G. Daatselaar, H. Prins

Dit onderzoek is uitgevoerd door Wageningen Economic Research in opdracht van en gefinancierd door de Raad voor de leefomgeving en infrastructuur (Rli)

Wageningen Economic Research

Wageningen, April 2020

RAPPORT

2020-017c

ISBN 978-94-6395-407-5 
Daatselaar, C.H.G., H. Prins, 2020. Vernatting Groene Hart: kostprijs melk en $\mathrm{CO}_{2}$-prijs. Wageningen, Wageningen Economic Research, Rapport 2020-017c. 20 blz.; 2 fig.; 9 tab.; 11 ref.

De kostprijs van melk in het Groene Hart is met een niveau van bijna 41 euro per $100 \mathrm{~kg}$ melk vergelijkbaar met de kostprijs van melk in overig Nederland maar is wel 2,50 euro hoger dan in Denemarken en ruim 10 euro hoger dan in Ierland. Bij verhoging van het slootwaterpeil in het Groene Hart met $20 \mathrm{~cm}$ om bodemdaling en $\mathrm{CO}_{2}$-uitstoot te verminderen is een vergoeding van 41 euro per ton verminderde $\mathrm{CO}_{2}$-uitstoot nodig als compensatie voor gederfde grasopbrengsten en extra kosten.

Trefwoorden: Groene Hart, kostprijs melk, $\mathrm{CO}_{2}$-prijs

Dit rapport is gratis te downloaden op https://doi.org/ 10.18174/521612 of op www.wur.nl/ economic-research (onder Wageningen Economic Research publicaties).

(C) 2020 Wageningen Economic Research

Postbus 29703, 2502 LS Den Haag, T 07033583 30, E communications.ssg@wur.nl, www.wur. nl/economic-research. Wageningen Economic Research is onderdeel van Wageningen University \& Research.

\section{(cc) BY-NC}

Dit werk valt onder een Creative Commons Naamsvermelding-Niet Commercieel 4.0 Internationaallicentie.

(C) Wageningen Economic Research, onderdeel van Stichting Wageningen Research, 2020

De gebruiker mag het werk kopiëren, verspreiden en doorgeven en afgeleide werken maken. Materiaal van derden waarvan in het werk gebruik is gemaakt en waarop intellectuele eigendomsrechten berusten, mogen niet zonder voorafgaande toestemming van derden gebruikt worden. De gebruiker dient bij het werk de door de maker of de licentiegever aangegeven naam te vermelden, maar niet zodanig dat de indruk gewekt wordt dat zij daarmee instemmen met het werk van de gebruiker of het gebruik van het werk. De gebruiker mag het werk niet voor commerciële doeleinden gebruiken.

Wageningen Economic Research aanvaardt geen aansprakelijkheid voor eventuele schade voortvloeiend uit het gebruik van de resultaten van dit onderzoek of de toepassing van de adviezen.

Wageningen Economic Research is ISO 9001:2015 gecertificeerd.

Wageningen Economic Research Rapport 2020-017c | Projectcode 2282200561

Foto omslag: Shutterstock 


\section{Inhoud}

$\begin{array}{lll}2.1 & \text { Methodiek en gegevens } & 7\end{array}$

2.2 Vergelijking Groene Hart met Nederland klei en zand 8

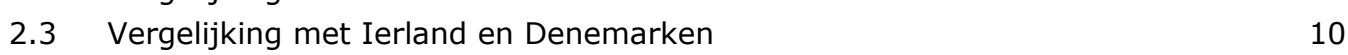

3.1 Methodiek 12

3.1 .1 Basismodel $\quad 12$

3.1.2 Uitgangspunten 13

3.2 Resultaten 13

3.2.1 Effecten voor de verschillende kostenposten 13

$\begin{array}{ll}3.2 .2 \text { Effect op de kostprijs van melk } & 14\end{array}$

3.2.3 Effect op de emissies van broeikasgassen $\quad 15$

$\begin{array}{lll}4.1 & \text { Kostprijs melk } & 17\end{array}$

4.2 Effecten van vernatting op kosten, kostprijs en $\mathrm{CO}_{2}$-emissie 17

$\begin{array}{lll}4.3 & \text { Discussie } & 18\end{array}$

$\begin{array}{lr}\text { Literatuur en websites } & 19\end{array}$ 



\section{$1 \quad$ Aanleiding en onderzoeksvragen}

De Raad voor de leefomgeving en infrastructuur (Rli) bereidt een advies voor over bodemdaling in het veenweidegebied het Groene Hart. De adviesvragen luiden: welke keuzes moeten worden gemaakt in verband met de negatieve effecten van bodemdaling in het veenweidegebied het Groene Hart en door wie? En wat is de rol van het Rijk daarbij?

Rli heeft geconstateerd dat in veel gebieden in Nederland de bodem zakt, vooral in veenweidegebieden. Dit proces is al eeuwenlang gaande maar is de afgelopen honderd jaar geïntensiveerd door peilverlaging. Op sommige plekken zakt de bodem met enkele centimeters per jaar. Bodemdaling zorgt voor problemen, zoals verzakking van infrastructuur en gebouwen, $\mathrm{CO}_{2}$-uitstoot door veenoxidatie en achteruitgang van waterkwaliteit en bodemleven. Bovendien zijn er negatieve gevolgen voor het gebruik van landbouwgronden. De gangbare manier om hiermee om te gaan, namelijk verlaging van het waterpeil, is op de lange termijn niet overal houdbaar. In het klimaatakkoord is afgesproken dat $\mathrm{CO}_{2}-$ emissies drastisch omlaag moeten, ook die van de veenweidegebieden.

De commissie die het Rli-advies voorbereidt heeft twee onderzoeksthema's aan Wageningen Economic Research voorgelegd.

\section{1) Kostprijs van melk}

De onderzoeksvragen bij het eerste thema luiden: Hoe verhoudt de kostprijs van melk in het veenweidegebied het Groene Hart zich tot de kostprijs van melk in de rest van Nederland (op klei en zand) en de kostprijs van melk in naburige landen? In hoeverre kunnen de door melkveehouders in het Groene Hart ontwikkelde 'compensatiestrategieën' van invloed zijn op hun bedrijfsvoering?

De melkveehouderij heeft een bijzondere positie in het veenweidegebied Groene Hart. Zij is een belangrijke grondgebruiker in het gebied en drager van het veenweidelandschap en ook belanghebbende bij voortgaande peilverlaging. Terwijl andere beleidsopgaven zoals de klimaatopgave of de wateropgave (deels) kunnen meeliften met oplossingen voor het tegengaan van bodemdaling (het verhogen van het waterpeil), doet de melkveehouderij dat niet. De melkveehouderij heeft geen belang bij peilverhoging omdat een verhoging van het waterpeil nadelig zou kunnen zijn voor de bedrijfsvoering. En het lijkt erop dat de marges in de melkveehouderij in het Groene Hart toch al klein zijn. Het roept de vraag op of die marges kleiner zijn voor melkveehouderijen in het Groene Hart dan voor melkveehouderijen op klei en zand. Moeten melkveehouders in het Groene Hart inderdaad meer kosten maken om het bedrijf draaiende te houden? En hoe is dat binnen Europa, waar de melkveehouderij in het Groene Hart mee moet concurreren? Deze vragen wil de commissie graag laten onderzoeken. Dat is mogelijk aan de hand van een vergelijkende studie naar de kostprijs van melk. Daarbij kan kwalitatief (in woorden) worden belicht in hoeverre melkveehouderijen in het Groene Hart profiteren van de diverse compensatiestrategieën die zij hebben ontwikkeld vanuit hun ligging bij de Randstad zoals inkomen uit boerenkaas, baan in de stad of inkomsten uit recreatie. In droogteperioden hebben melkveehouderijen in het Groene Hart overigens juist concurrentievoordeel ten opzichte van boeren op klei en zand.

\section{2) $\mathbf{C O}_{2}$-prijs en bedrijfsomvang}

De onderzoeksvragen bij het tweede thema zijn: bij welke $\mathrm{CO}_{2}$-prijs gaat het bedrijfsresultaat niet omlaag in geval van aanpassing van het bedrijfsmodel als gevolg van vernatting en in hoeverre speelt de bedrijfsomvang een rol in het niveau van de benodigde $\mathrm{CO}_{2}$-prijs?

Een mogelijkheid om bodemdaling en de daarmee gepaard gaande broeikasgasemissie op veengrond te verminderen is het verhogen van het waterpeil. Het gevolg daarvan is dat agrariërs in het Groene Hart te maken krijgen met vernatting van hun percelen, wat negatieve gevolgen kan hebben voor hun bedrijfsresultaat. 
Een denkbare oplossing voor teruglopende financiële resultaten is een nieuw verdienmodel waarbij het tegengaan van bodemdaling en/of de reductie van broeikasgasemissie wordt aangemerkt als een maatschappelijke dienst. Ook kan gekeken worden naar min of meer commerciële vermarkting op de vrijwillige koolstofmarkt via uitgifte van certificaten.

De vraag is hoe hoog de vergoeding voor de maatschappelijke dienst ofwel de prijs per $\mathrm{kg} \mathrm{CO}_{2}$ moet zijn om de financiële resultaten niet te laten teruglopen. Van een vergoeding zal overigens alleen sprake zijn bij verhoging van het waterpeil. De hoogte van de $\mathrm{CO}_{2}$-prijs zou kunnen samenhangen met de bedrijfsomvang: bij een voldoende groot bedrijf kan de $\mathrm{CO}_{2}$-beprijzing mogelijk lager zijn. De hoogte van de $\mathrm{CO}_{2}$-prijs is niet alleen afhankelijk van de mate van vermindering van de drooglegging maar ook van de beginsituatie. Het is voor agrariërs lastiger als de verhoging van het waterpeil van $40 \mathrm{~cm}$ naar $20 \mathrm{~cm}$ onder het maaiveld gaat dan eenzelfde verhoging met $20 \mathrm{~cm}$ van $80 \mathrm{~cm}$ naar $60 \mathrm{~cm}$ onder het maaiveld. 


\section{Kostprijs van melk}

\subsection{Methodiek en gegevens}

Melkveehouders maken kosten voor de productie van melk. Tegelijkertijd wordt met melk ook vlees geproduceerd: vaak wordt elk jaar $25-30 \%$ van de melkkoeien afgevoerd en $60-70 \%$ van de jaarlijks geboren kalveren verlaat voor de leeftijd van 1 maand het bedrijf. Verder zijn er ook bij sommige bedrijven opbrengsten uit andere activiteiten zoals recreatie of zorglandbouw.

Voor de berekening van de kostprijs wordt de methodiek toegepast die de Europese Commissie gebruikt in haar Dairy Reports (EU, 2018). Niet alle kosten, vooral die voor eigen arbeid, zijn goed uit te splitsen naar de verschillende opbrengsten. Daarom wordt berekend wat het procentuele aandeel van de aan melk gerelateerde opbrengst (melk, vlees, betalingen vanuit de Europese Unie: deze betalingen zijn aan de grond verbonden) in de totale opbrengst is. Dit percentage wordt toegepast op kostenposten die moeilijk of niet zijn uit te splitsen (zoals dus arbeid maar ook wel gebouwen en machines). Kosten voor bijvoorbeeld aangekocht voer kunnen wel aan de melkveestapel worden toegerekend: dan is een correctie met het procentuele aandeel van de aan melk gerelateerde opbrengst in de totale opbrengsten niet nodig.

Door zo alle kostenposten vast te stellen, zijn de aan melkproductie gerelateerde kosten per (100) kg melk te berekenen. Daarna wordt berekend wat het aandeel van melk (de melkprijs per $100 \mathrm{~kg}$ melk) in de aan melk gerelateerde opbrengsten is. Vermenigvuldigen van dit aandeel (vaak tussen 80 en $90 \%$ ) met de kosten van de melkproductie levert dan de kostprijs per (100) kg melk op.

Tegenover een hogere kostprijs kan een hogere melkprijs staan. Dit is bijvoorbeeld duidelijk het geval bij bedrijven met een biologische bedrijfsvoering (www.agrimatie.nl). De kosten om neveninkomsten te genereren zitten door de hiervoor beschreven toerekeningen niet in de kostprijs van melk. Wel kan een netto-opbrengstcompensatiestrategie zeer welkom zijn om bijvoorbeeld het totale inkomen te verhogen bij een kleinere omvang van de melkproductie op het bedrijf of om eventueel ruimer beschikbare arbeid tot waarde te brengen.

Voor de Nederlandse cijfers omtrent kostprijs, opbrengstprijs en neveninkomsten is gebruikgemaakt van het Bedrijveninformatienet van Wageningen Economic Research. Het Bedrijveninformatienet is een representatieve steekproef van de Nederlandse land- en tuinbouw (Ge et al., 2018) die al vele jaren bestaat. Om schommelingen in onder andere prijzen wat op te vangen (2016 kende een lage melkprijs en 2017 juist een hoge) zijn de resultaten van de drie meest recente beschikbare jaren, 2016 tot en met 2018, gemiddeld. De droogte van 2018 valt zo ook te 'compenseren' met het goede groeijaar 2017. De melkveebedrijven in het Groene Hart worden vergeleken met de Nederlandse melkveebedrijven op zand en klei.

Om na te gaan of een eventueel hogere kostprijs van melk in het Groene Hart een concurrentienadeel kan betekenen met het buitenland wordt ook een vergelijking gemaakt met Ierland en Denemarken. Elke lidstaat van de Europese Unie (EU) moet een netwerk zoals het Bedrijveninformatienet bijhouden. Gezamenlijk vormen deze netwerken het Europese Farm Accountancy Data Network (FADN). Gemiddelden van minimaal (onder andere om de privacy te borgen) 15 individuele bedrijven zijn publiek beschikbaar via de website van de FADN Public Database. Hiervan is gebruikgemaakt om kostprijzen in Ierland en Denemarken te berekenen. Ierland is een goede representant van een bedrijfssysteem met veel weiden en in Denemarken staat het grootste deel van de koeien het gehele jaar op stal. Deze systemen zijn behoorlijk gemeengoed in Nederland. Beide landen hebben wel wat variatie in productieomstandigheden maar veel minder dan landen als Duitsland, Frankrijk en het Verenigd Koninkrijk. De FADN-cijfers zijn geijkt met nationale cijfers (Teagasc $(2018,2019)$, BAL (2018)). 


\subsection{Vergelijking Groene Hart met Nederland klei en zand}

Tabel 2.1 geeft enkele kengetallen omtrent de bedrijfsstructuur en de bedrijfsvoering voor de melkveebedrijven in het Groene Hart en de melkveebedrijven op klei en zand. De bedrijven in het Groene Hart hebben gemiddeld minder land in gebruik dan de melkveebedrijven op klei en zand. Maar ze gebruiken wel bijna alles voor de melkveehouderij en hebben ook bijna alle land in gebruik als grasland. Het aantal koeien per hectare is in het Groene Hart ook lager.

Omdat de melkproductie per koe in het Groene Hart ook nog ruim $600 \mathrm{~kg}$ lager is dan bij de melkveebedrijven op klei en zand, is de totale melkproductie per bedrijf in het Groene Hart ruim een kwart lager - $648.000 \mathrm{~kg}$ tegen $885.000 \mathrm{~kg}$ - dan bij de melkveebedrijven op klei en zand.

Tabel 2.1 Bedrijfsstructuur en bedrijfsvoering van melkveebedrijven in het Groene Hart en op klei en zand, gemiddeld over de jaren 2016-2018

\begin{tabular}{lrr} 
& Groene Hart & 49,90 \\
Ha cultuurgrond & 49,75 & 56,01 \\
\hline waarvan voor melkvee & 96 & 53,33 \\
\hline Percentage grasland & 79,5 & 100,6 \\
\hline Aantal melkkoeien & 1,60 & 1,89 \\
\hline Melkkoeien per ha & 648.000 & 885.000 \\
\hline Kg melkproductie per bedrijf & 8.160 & 8.790 \\
\hline Kg melkproductie per koe & & \\
\hline
\end{tabular}

Bron: Bedrijveninformatienet van Wageningen Economic Research

Tabel 2.2 beschrijft de aan de melkproductie gerelateerde opbrengsten en kosten per $100 \mathrm{~kg}$ melk. De kosten voor aangekocht voer, voor vee en voor gewas worden variabele kosten genoemd. De andere kosten worden onder vaste kosten gerubriceerd. Voor arbeid van de ondernemer(s) en meewerkende gezinsleden wordt een berekend uurloon gebruikt (tussen 25 en 30 euro, onder andere afhankelijk van leeftijd). Voor het vermogen in het bedrijf wordt een rentepercentage berekend dat afhangt van het type activum: voor grond wordt bijvoorbeeld een ander rentepercentage gebruikt dan voor machines. Omdat de berekende rente over alle activa wordt berekend, wordt de betaalde rente uit de kostprijs gelaten: anders zou er meer of minder dubbele rente in rekening gebracht worden.

Tabel 2.2 Aan de melkproductie gerelateerde kosten (euro per $100 \mathrm{~kg}$ melk) op melkveebedrijven in het Groene Hart en op klei en zand, gemiddeld over de jaren 2016-2018

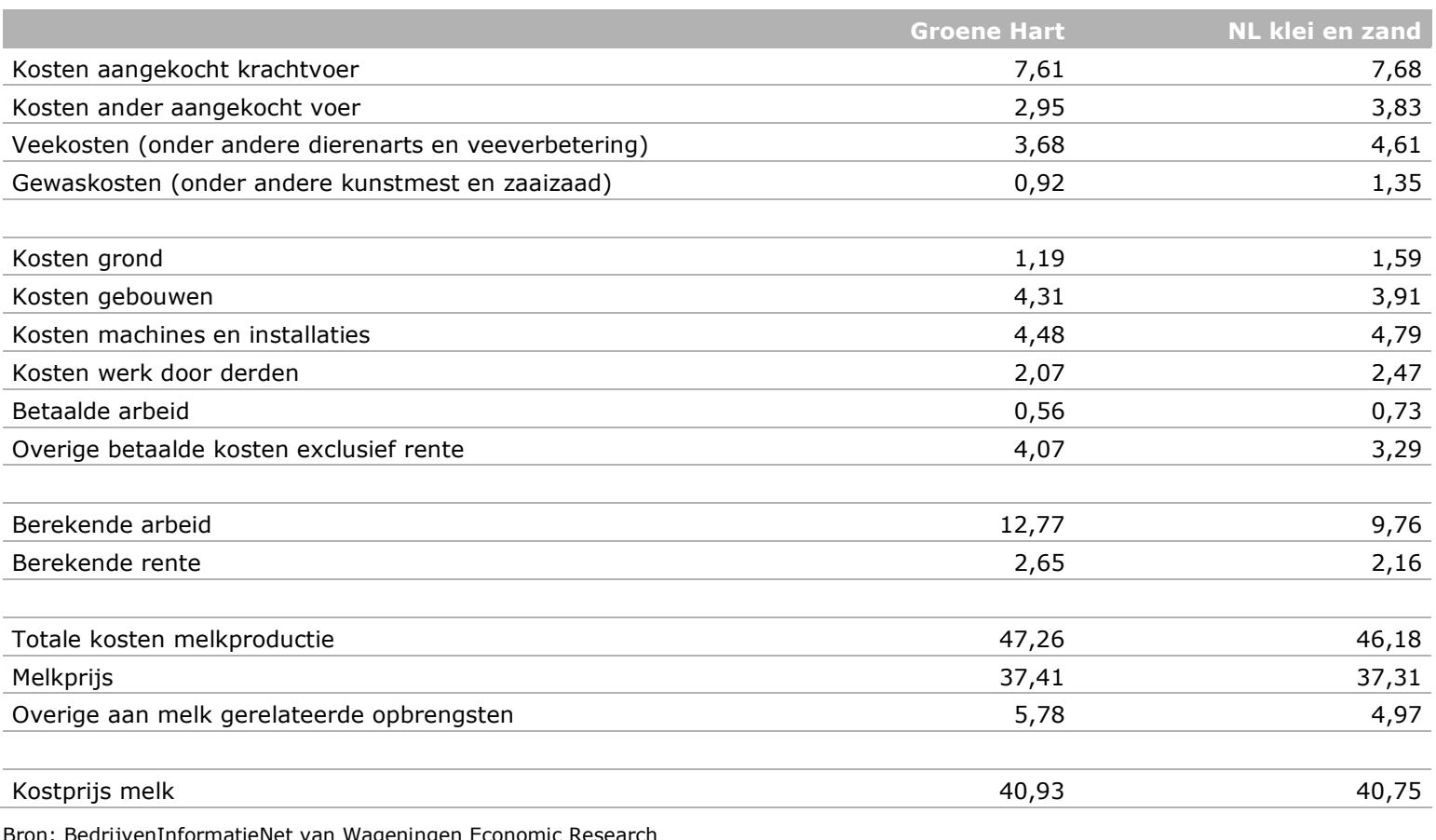


De kosten voor grond betreffen vooral pacht maar ook de jaarlijkse waterschapsbelasting. In het Groene Hart wordt relatief minder land gepacht zodat de betaalde bedragen voor grond lager zijn maar daar staat een hogere berekende rente, vanwege het hogere aandeel eigen grond, tegenover.

De melkveebedrijven in het Groene Hart realiseren lagere variabele kosten per $100 \mathrm{~kg}$ melk dan de melkveebedrijven op klei en zand. Het verschil is ruim 2 euro per $100 \mathrm{~kg}$ melk doordat de melkveebedrijven in het Groene Hart minder ruwvoer aankopen, minder veekosten hebben en minder gewaskosten maken, vooral omdat zij minder snijmais telen.

Bij de vaste kosten is het echter meer dan andersom: daar komen de melkveebedrijven in het Groene Hart ruim 3 euro per $100 \mathrm{~kg}$ melk hoger uit. Dat zit grotendeels in meer kosten voor berekende arbeid. Op de melkveebedrijven in het Groene Hart werken gemiddeld nagenoeg evenveel onbetaalde arbeidskrachten $(1,49)$ als op de melkveebedrijven op klei en zand $(1,57)$ terwijl de melkproductie per bedrijf flink verschilt (zie tabel 2.1). De melkveehouders in het Groene Hart voeren relatief meer werkzaamheden zelf uit en er wordt minder aan de loonwerker (werk door derden) uitbesteed.

De totale kosten per $100 \mathrm{~kg}$ melk voor melkproductie pakken daardoor hoger uit in het Groene Hart. Daar staat een hogere opbrengst uit onder andere verkoop van vee tegenover zodat de kostprijs van melk nagenoeg gelijk is. De kostprijs van melk voor het Groene Hart vanuit de totale kosten voor melkproductie is 47,26 [totale kosten melkproductie] x 37,41 [melkprijs] / $(37,41+5,78$ [alle aan melk gerelateerde opbrengsten] $)=40,93$ euro/100 kg melk. Met dezelfde rekenwijze komt de kostprijs voor melkveebedrijven op klei en zand uit op 40,75 euro/100 kg melk.

Kijken we naar het inkomen per $100 \mathrm{~kg}$ melk (in plaats van de berekende arbeid en de berekende rente wordt dan de betaalde rente meegenomen), dan is er een verschil in het voordeel van de melkveebedrijven in het Groene Hart: 7,25 tegenover 4,59 euro per $100 \mathrm{~kg}$ melk. Op bedrijfsniveau is dat 54.300 tegen 45.900 euro.

Naast het direct aan de melkproductie gerelateerde inkomen zijn er op een aantal melkveebedrijven ook nog andere bronnen van inkomsten. Te denken valt aan inkomen uit recreatie of een zorgtak. Ook kunnen één of meer gezinsleden een baan buiten het bedrijf hebben. Deze aanvullende inkomensbronnen kunnen een eventueel te gering inkomen opvijzelen. Tabel 2.3 geeft de bedragen weer van een aantal neveninkomsten.

Tabel 2.3 Enkele neveninkomsten (euro per bedrijf) van melkveebedrijven in het Groene Hart en op klei en zand, gemiddeld over de jaren 2016-2018

\begin{tabular}{lrr} 
& Groene Hart & 16.900 \\
Andere inkomsten uit bedrijf & 2.100 & 1.700 \\
\hline waarvan uit recreatie & 4.700 & 2.100 \\
\hline waarvan uit natuur- en beheerssubsidies & 1.300 & 1.700 \\
\hline waarvan uit een zorgtak & 4.500 & 7.700 \\
\hline Inkomen uit arbeid buiten het bedrijf & & 75.700 \\
\hline Inkomen uit bedrijf + inkomen uit arbeid buiten het bedrijf & 68.300 \\
\hline
\end{tabular}

Bron: BedrijvenInformatieNet van Wageningen Economic Research

De melkveebedrijven in het Groene Hart realiseren gemiddeld meer andere inkomsten uit het bedrijf via recreatie en natuur-/beheerssubsidies maar minder uit een zorgtak. Het inkomen uit werk buiten het bedrijf is op de melkveebedrijven in het Groene Hart lager dan bij de melkveebedrijven op klei en zand. Alles bij elkaar genomen is er geen sprake van meer compensatie door neveninkomsten bij melkveebedrijven in het Groene Hart ten opzichte van de melkveebedrijven op klei en zand en behalen de melkveebedrijven in het Groene Hart een totaal inkomen dat ruim 7.000 euro per bedrijf hoger is. 
Het inkomen uit bedrijf + inkomen buiten bedrijf is enigszins vergelijkbaar met het bruto-jaarloon van werknemers. Er moet nog belasting over worden betaald en ook de privé-uitgaven moeten eruit voldaan worden. Belangrijk aandachtspunt is wel dat de ondernemers hun pensioenvoorziening en ook de premies voor arbeidsongeschiktheidsverzekeringen volledig uit dit inkomen moeten halen; bij werknemers neemt de werkgever een groter of kleiner deel van deze posten voor zijn rekening. Verder gelden de bedragen voor ongeveer anderhalve persoon (respectievelijk 1,49 en 1,57 onbetaalde arbeidskracht per bedrijf) zodat het inkomen uit bedrijf + inkomen buiten bedrijf per onbetaalde arbeidskracht respectievelijk 50.900 en 43.500 euro is.

De conclusie is dat hoewel de melkveebedrijven in het Groene Hart kleiner en extensiever zijn dan de melkveebedrijven op klei en zand, ze qua kostprijs (minder dan 0,5\% hoger) en melkprijs (ook minder dan $0,5 \%$ hoger) vrijwel gelijk uitkomen.

\subsection{Vergelijking met Ierland en Denemarken}

Net zoals Nederland exporteren ook Ierland en Denemarken een aanzienlijk deel van hun zuivelproductie. De meeste andere Europese landen exporteren een beperkt deel of zijn netto importerend voor zuivelproducten. Ierland en Denemarken zijn beide niet veel groter dan Nederland waardoor er minder variatie in productiesysteem is binnen het land dan in grote landen als Duitsland, Frankrijk en het Verenigd Koninkrijk. In Ierland worden de koeien een groot deel van het jaar geweid, 8 tot 10 maanden, terwijl in Denemarken de koeien bijna allemaal het gehele jaar in de stal blijven. Nederland neemt betreffende het weiden een tussenpositie in: gemiddeld zijn de koeien, in uren gemeten, 10-15\% van het jaar buiten.

Tabel 2.4 geeft enkele kengetallen omtrent de bedrijfsstructuur en de bedrijfsvoering voor de melkveebedrijven in het Groene Hart en de melkveebedrijven in Ierland en Denemarken. De melkveebedrijven in Ierland en Denemarken hebben meer grond in gebruik dan die in het Groene Hart. Het aantal koeien per bedrijf in het Groene Hart is weinig groter dan in Ierland en nog niet de helft van dat in Denemarken. Wel is het aantal koeien per hectare in Ierland en Denemarken lager dan in het Groene Hart terwijl het Groene Hart lager zit dan de Nederlandse melkveebedrijven op klei en zand (tabel 2.1). Qua melkproductie per bedrijf en per koe neemt het Groene Hart een tussenpositie in.

Tabel 2.4 Bedrijfsstructuur en bedrijfsvoering van melkveebedrijven in het Groene Hart, Ierland en Denemarken, gemiddeld over de jaren 2016-2018

\begin{tabular}{lrrr} 
& Groene Hart & Ierland & Denemarken \\
Ha cultuurgrond voor melkvee & 49,75 & 58,41 & 113,10 \\
\hline Aantal melkkoeien & 79,5 & 167,7 \\
\hline Melkkoeien per ha & 1,60 & 1,29 & 1,48 \\
\hline Kg melkproductie per bedrijf & 648.000 & 432.000 & 1.607 .000 \\
\hline Kg melkproductie per koe & 8.160 & 5.740 & 9.580 \\
\hline
\end{tabular}

Bron: BedrijvenInformatieNet van Wageningen Economic Research en bewerking van FADN Public Database door Wageningen Economic Research

Tabel 2.5 geeft de kosten en opbrengsten per $100 \mathrm{~kg}$ melk voor melkveebedrijven in het Groene Hart, Ierland en Denemarken. De kostprijs per $100 \mathrm{~kg}$ melk is in Ierland flink lager, ongeveer drie kwart van die in het Groene Hart. Ook in Denemarken is de kostprijs lager, ongeveer 6\%. Daar staat wel een hogere melkprijs tegenover in het Groene Hart. Door het systeem van veel weiden kent Ierland een piek in de melkproductie in het 2e kwartaal van het jaar terwijl in het 1e kwartaal bijna alle koeien 2 maanden droog staan. Zuivelverwerkers in Ierland hebben daardoor in de eerste 3 maanden van het jaar een forse onderbenutting van de capaciteit wat tot hogere verwerkingskosten leidt. Verder is het moeilijk om de piek in het 2e kwartaal in zijn geheel goed te verwaarden: er wordt dan relatief meer boter en melkpoeder met beperkte toegevoegde waarde geproduceerd. 
Denemarken en vooral Ierland zetten wel hogere opbrengsten uit verkoop van vee tegenover de lagere melkprijs. In Ierland houden melkveebedrijven naast de melkkoeien ook nog een aantal stuks vleesvee.

De Nederlandse melkveebedrijven, ook die in het Groene Hart, hebben het dus qua kostprijs en ook qua marge niet eenvoudig ten opzichte van Ierland en Denemarken. De Nederlandse zuivelverwerkers zullen veel toegevoegde waarde uit de melk (via speciale producten uit melk zoals babymelkpoeder) moeten halen zodat de Nederlandse melkveehouders via een hogere melkprijs beter kunnen concurreren met de tegen lage kosten producerende melkveebedrijven in Ierland en met de, via schaalgrootte, efficiënte Deense melkveebedrijven.

Tabel 2.5 Aan de melkproductie gerelateerde kosten (euro per $100 \mathrm{~kg}$ melk) van melkveebedrijven in het Groene Hart, Ierland en Denemarken, gemiddeld over de jaren 2016-2018

\begin{tabular}{|c|c|c|c|}
\hline & Groene Hart & Ierland & Denemarken \\
\hline Kosten aangekocht krachtvoer & 7,61 & 10,06 & 11,73 \\
\hline Kosten ander aangekocht voer & 2,95 & & \\
\hline Gewaskosten (onder andere kunstmest en zaaizaad) & 0,92 & 1,42 & 1,89 \\
\hline Kosten machines en installaties & 4,48 & 3,11 & 4,82 \\
\hline Kosten werk door derden & 2,07 & 1,49 & 3,33 \\
\hline Betaalde arbeid & 0,56 & 1,11 & 4,28 \\
\hline Overige betaalde kosten exclusief rente & 4,07 & 0,88 & 1,56 \\
\hline Totale kosten melkproductie & 47,26 & 42,75 & 46,33 \\
\hline Melkprijs & 37,41 & 31,25 & 36,78 \\
\hline Overige aan melk gerelateerde opbrengsten & 5,78 & 12,48 & 7,50 \\
\hline Kostprijs melk & 40,93 & 30,55 & 38,48 \\
\hline
\end{tabular}

Bron: Bedrijveninformatienet van Wageningen Economic Research en bewerking van FADN Public Database door Wageningen Economic Research 


\section{Effecten van vernatting op kosten, kostprijs en $\mathrm{CO}_{2}$-emissie}

\subsection{Methodiek}

\subsubsection{Basismodel}

Dit hoofdstuk gaat in op het tweede onderzoeksthema, namelijk de effecten van het opzetten van het waterpeil op de bedrijfsresultaten van de melkveehouders (naar bedrijfsomvang) en de vermindering van de emissie van broeikasgassen. Een soortgelijk onderzoek is uitgevoerd voor het Friese veenweidegebied (Prins et al., 2018). In dat onderzoek is rekening gehouden met een groot aantal effecten van peilverhoging op zowel de agrarische bedrijfsvoering als op de emissies van broeikasgassen. Het conceptueel concept en het rekenmodel zijn overgenomen uit die notitie. Waar nodig zijn aanpassingen gedaan door bepaalde coëfficiënten in het model aan te passen aan de situatie in het Groene Hart.

Figuur 3.1 laat zien hoe de verschillende effecten in het conceptueel model zijn opgenomen. Een geringere drooglegging (=verhoging van het slootwaterpeil) leidt tot een verhoging van de grondwaterstand en tot vernatting van de bodem. De fysieke effecten daarvan zijn:

- De veenoxidatie vermindert omdat er minder zuurstof in de bodem voorkomt. Minder veenoxidatie leidt automatisch tot beperking van de bodemdaling, tot lagere broeikasgasemissies en tot minder bodemmineralisatie. De effecten op de bodemdaling en de broeikasgasemissie kunnen gezien worden als maatschappelijke baten.

- De nattere omstandigheden leiden tot een lagere bodemtemperatuur. Dat leidt tot een vertraagde grasgroei en een lagere voedingswaarde van het gras. Dit laatste wordt nog versterkt door te verwachten veranderingen in het grasbestand waarbij, vanuit landbouwkundig oogpunt, goede grassen zich minder goed kunnen handhaven en slechtere grassen en onkruiden hun plaats zullen innemen. Financieel betekent dit hogere voerkosten en wellicht een besparing op de oogst- en bemestingskosten.

- De draagkracht van de bodem neemt af (- in figuur 3.1). Dit heeft gevolgen voor de uitvoering van veldwerkzaamheden en voor de beweiding. Ook zal het grasbestand extra te lijden hebben in verband met vertrapping door het vee. Het leidt tot extra kosten voor veldwerk en voor graslandherstel. 


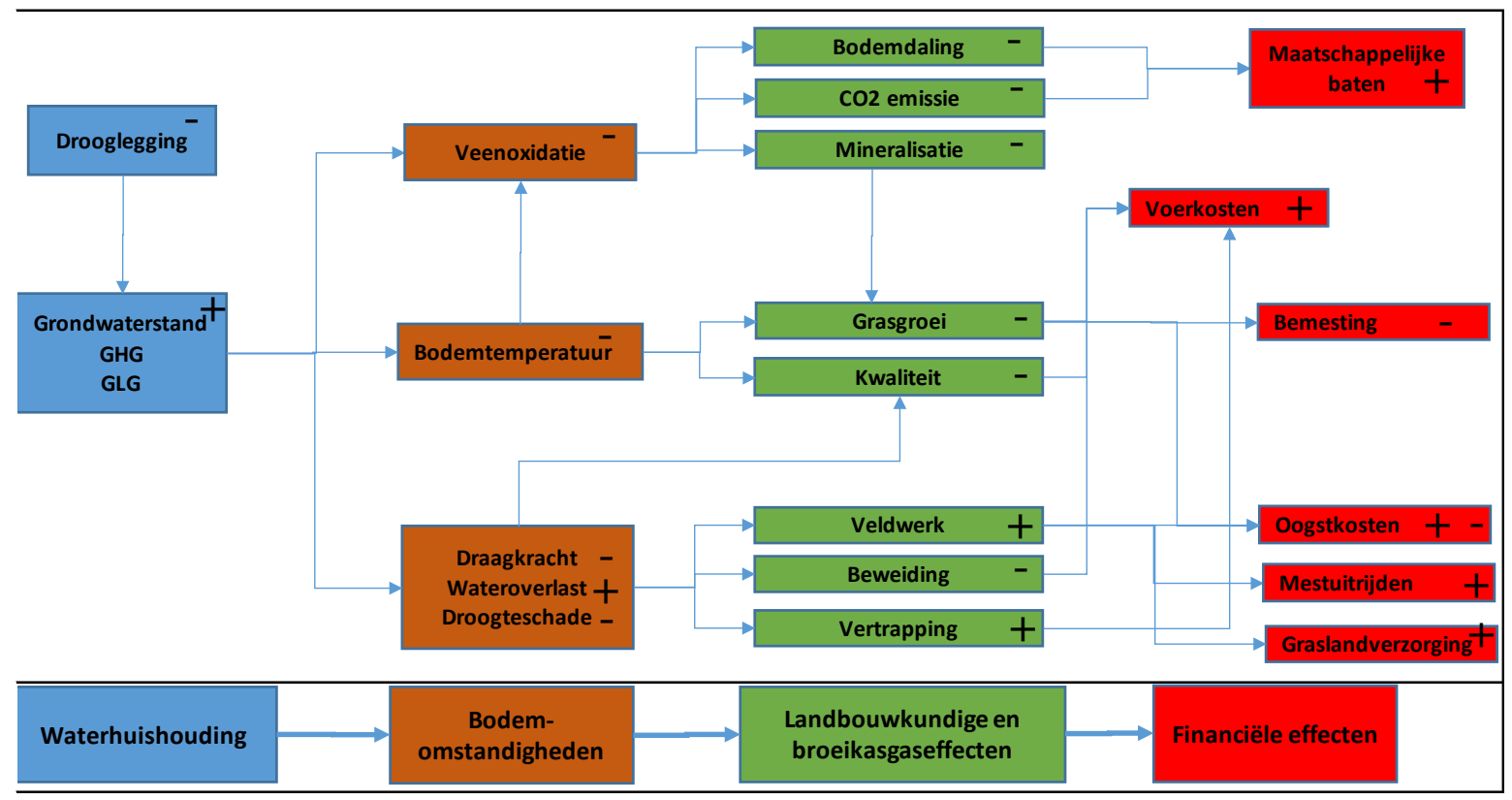

Figuur 3.1 Conceptueel model effecten van peilverhoging op bedrijfsvoering en -omvang en op broeikasgasemissies (GHG: Gemiddeld Hoogste Grondwaterstand, GLG: Gemiddeld Laagste Grondwaterstand) (- is minder, + is meer)

\subsubsection{Uitgangspunten}

Voor deze studie zijn in principe dezelfde uitgangspunten gebruikt als in Prins et al. (2018). In dat rapport is de kwantificering van de effecten van vernatting op de emissie van broeikasgassen en op de diverse opbrengsten- en kostenposten uitgebreid gerapporteerd. In de notitie zijn de rekenregels expliciet opgenomen met bronvermelding. Ook is daarin beschreven hoe de effecten op het bedrijfsresultaat worden uitgedrukt per $\mathrm{kg}$ verminderde $\mathrm{CO}_{2}$-emissie. Voor de details wordt verwezen naar de notitie die op verzoek bij de auteurs kan worden verkregen.

In het Groene Hart is het veen relatief goed doorlatend en de percelen zijn over het algemeen smal. Dat leidt ertoe dat de grondwaterstand zowel in de zomer als in de winter het slootpeil beter volgt dan in het Noordelijk veengebied waar de percelen (veel) breder zijn en een groot deel van het veen slecht doorlatend is. Om die reden ervaren agrariërs in het Groene Hart bij een gelijke drooglegging minder snel waterhuishoudelijke problemen dan hun collega's op veengrond in het noorden des lands.

Om de uitgangspunten van de studie Prins et al. (2018), die voor Friesland zijn opgesteld, passend te maken voor de situatie in het Groene Hart is een aanpassing gedaan: het verschil tussen het slootpeil en de Gemiddeld Laagste Grondwaterstand is gehalveerd en het verschil in slootpeil en Gemiddeld Hoogste Grondwaterstand is met $5 \mathrm{~cm}$ teruggebracht. Deze aanpassing heeft vooral invloed op de landbouwkundige effecten van peilaanpassing. De invloed van deze aanpassing op de $\mathrm{CO}_{2}$-emissie is vrijwel nihil.

\subsection{Resultaten}

\subsubsection{Effecten voor de verschillende kostenposten}

In overleg met de opdrachtgever zijn voor deze studie de landbouwkundige effecten berekend bij een verhoging van het slootwaterpeil met $20 \mathrm{~cm}$. Tabel 3.1 laat de meerkosten zien van deze peilverhoging.

De meerkosten zijn sterk afhankelijk van de uitgangssituatie. Als uitgegaan wordt van diepe ontwatering, dan is het effect klein tot nihil. Een verhoging van het slootpeil van $100 \mathrm{~cm}$ naar $80 \mathrm{~cm}$ 
onder het maaiveld leidt bijvoorbeeld niet tot productiedervingen, belemmeringen bij veldwerkzaamheden of extra graslandonderhoud.

Tabel 3.1 Geschatte meerkosten bij vermindering van de drooglegging met $20 \mathrm{~cm}$ op veengrond in het Groene Hart onder verschillende uitgangssituaties (in Euro/ha cultuurgrond)

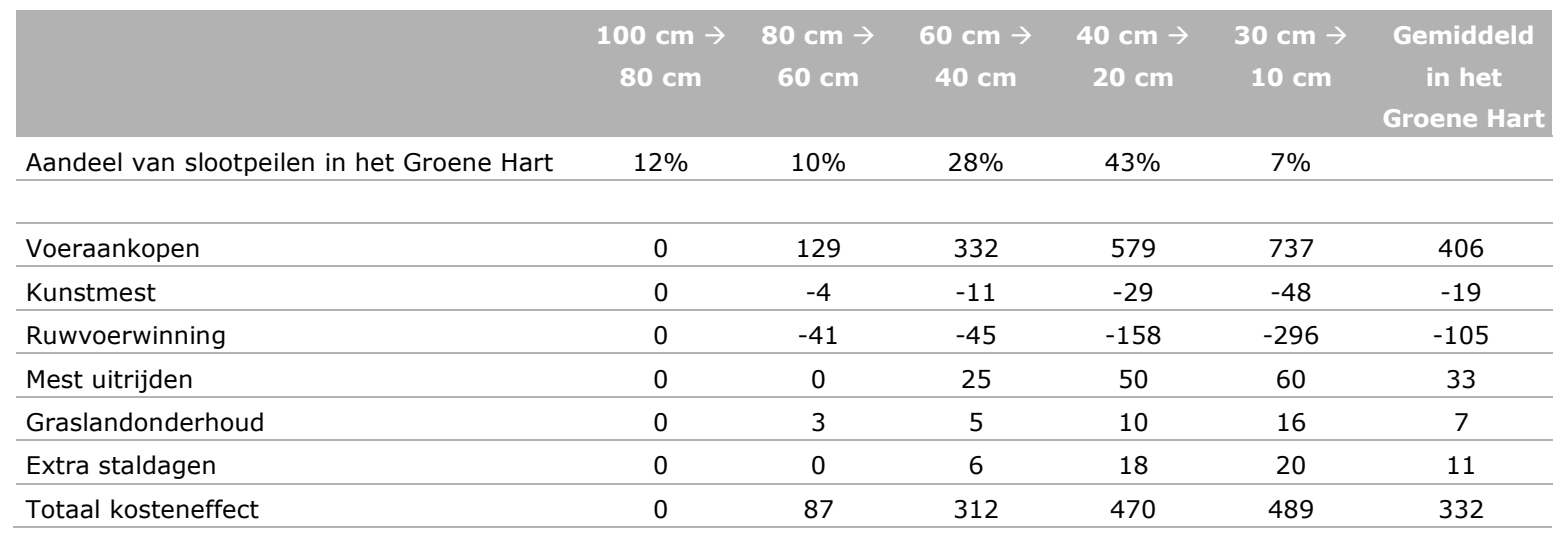

Wordt het slootpeil verhoogd van $80 \mathrm{~cm}$ naar $60 \mathrm{~cm}$ onder het maaiveld, dan is er wel opbrengstderving. De opbrengst van het grasland neemt dan met circa $5 \%$ af en ook de kwaliteit van het gras wordt iets lager. De opbrengstderving zal gecompenseerd moeten worden met extra voeraankopen. De kosten van deze extra aankopen belopen in dit geval 129 euro per ha. Daar staat tegenover dat er iets minder behoeft te worden bemest en er bespaard wordt op ruwvoerwinning. De gederfde graslandproductie hoeft immers niet te worden geoogst. Per saldo kost het opzetten van het slootwaterpeil met $20 \mathrm{~cm}$ in dit geval 87 euro per ha.

De uitgangssituatie is van grote invloed op de te verwachten meerkosten. Uit de tabel blijkt dat de opbrengst- en kwaliteitsdervingen groter zijn naarmate het slootpeil in de uitgangssituatie hoger is. Bovendien bemoeilijken de natte omstandigheden het veldwerk en moet er ook rekening gehouden worden met extra onderhoud voor de grasmat. Het vee zal vanwege natte omstandigheden eerder moeten worden opgestald, mede om vertrapping van weidegras en extra schade aan de grasmat te vermijden. Bij een uitgangssituatie van $30 \mathrm{~cm}$ gaat het slootpeil naar $10 \mathrm{~cm}$. In dat geval zal het grondwater regelmatig tot aan het maaiveld stijgen. De meerkosten bedragen in dat geval 489 euro per ha.

Deltares (2020) heeft gegevens van de huidige droogleggingen verstrekt. Van de 104.800 ha veengrond in het Groene Hart is $7 \%$ zeer ondiep ontwaterd $(<=30 \mathrm{~cm}$ ), $43 \%$ ondiep ontwaterd $(30-50 \mathrm{~cm}), 28 \%$ gemiddeld ontwaterd $(50-70 \mathrm{~cm}), 10 \%$ diep ontwaterd $(70-100 \mathrm{~cm})$ en $12 \%$ zeer diep ontwaterd $(>100 \mathrm{~cm})$.

Rekening houdend met deze verdeling komen de gemiddelde netto-meerkosten van peilverhoging uit op 332 euro/ha cultuurgrond. Voor een gemiddeld melkveebedrijf in het Groene Hart komt dat neer op een jaarlijkse inkomensderving van ruim 16.000 euro. Voor het gehele Groene Hart zijn de jaarlijkse kosten van een algemene peilverhoging van $20 \mathrm{~cm}$ naar schatting 35 miljoen euro, exclusief de kosten die door de waterschappen moeten worden gemaakt om deze peilverhoging mogelijk te maken.

\subsubsection{Effect op de kostprijs van melk}

In tabel 3.2 wordt berekend hoe groot het kosteneffect per geproduceerde hoeveelheid melk is. Op melkveebedrijven in het Groene Hart is de melkproductie gemiddeld ongeveer $13.000 \mathrm{~kg}$ per ha (tabel 2.1: 1,6 koe/ha x $8.170 \mathrm{~kg}$ melk/koe). De tabel laat zien dat ook de meerkosten per $\mathrm{kg}$ melk stijgen naarmate de uitgangssituatie ongunstiger is. 
Tabel 3.2 Geschatte meerkosten bij vermindering van de drooglegging met $20 \mathrm{~cm}$ op veengrond in het Groene Hart onder verschillende uitgangssituaties (in Euro/ha cultuurgrond)

\begin{tabular}{lcccccc} 
& $100 \mathrm{~cm} \rightarrow$ & $80 \mathrm{~cm} \rightarrow$ & $60 \mathrm{~cm} \rightarrow$ & $40 \mathrm{~cm} \rightarrow$ & $30 \mathrm{~cm} \rightarrow$ \\
& $80 \mathrm{~cm}$ & $60 \mathrm{~cm}$ & $40 \mathrm{~cm}$ & $20 \mathrm{~cm}$ & $10 \mathrm{~cm}$ \\
Aandeel van slootpeilen in het Groene Hart & $12 \%$ & $10 \%$ & $28 \%$ & $43 \%$ & $7 \%$ \\
\hline & & & & & \\
\hline Kosteneffect (euro/ha) & 0 & 87 & 312 & 470 & 489 \\
\hline Melkproductie (kg/ha) & 13.000 & 13.000 & 13.000 & 13.000 & 13.000 & 13.000 \\
\hline Kosteneffect (Euro/100 kg melk) & 0,00 & 0,70 & 2,40 & 3,60 & 3,80 & 2,60 \\
\hline
\end{tabular}

De kostprijs van melk, berekend op dezelfde wijze als in het voorgaande hoofdstuk, neemt toe van gemiddeld 40,93 euro/100 kg onder de huidige omstandigheden tot 43,15 euro bij een peilverhoging van $20 \mathrm{~cm}$. De hogere kosten zijn vooral te wijten aan opbrengst- en kwaliteitsdervingen van gras. Daarnaast zijn er hogere kosten voor mest uitrijden en graslandonderhoud. Besparingen worden gerealiseerd doordat er minder gras hoeft te worden geoogst en ingekuild en door iets minder kunstmest te gebruiken.

Tabel 3.3 Invloed op de gemiddelde kostprijs van melk bij vermindering van de drooglegging met $20 \mathrm{~cm}$ op veengrond in het Groene Hart (euro/100 kg melk)

\begin{tabular}{lrr} 
& Huidig peil & Peil \\
Totaal voerkosten & 10,56 & 13,77 \\
\hline Veekosten (onder andere dierenarts en veeverbetering) & 3,68 & 3,68 \\
\hline Gewaskosten (onder andere kunstmest en zaaizaad) & 0,92 & 0,82 \\
\hline Kosten grond & 1,19 & 1,19 \\
\hline Kosten gebouwen & 4,31 & 4,31 \\
\hline Kosten machines en installaties & 4,48 & 4,28 \\
\hline Kosten werk door derden & 2,07 & 1,82 \\
\hline Betaalde arbeid & 0,56 & 0,45 \\
\hline Overige betaalde kosten exclusief rente & 4,07 & 4,07 \\
\hline Berekende arbeid & 12,77 & 12,77 \\
\hline Berekende rente & 2,65 & 2,65 \\
\hline & & \\
\hline Totale kosten melkproductie & 47,26 & 49,82 \\
\hline Melkprijs & 37,41 & 37,41 \\
\hline Overige aan melk gerelateerde opbrengsten & 5,78 & 5,78 \\
\hline & & 43,15 \\
\hline Kostprijs melk & 40,93 & \\
\hline
\end{tabular}

\subsubsection{Effect op de emissies van broeikasgassen}

Verhoging van het slootwaterpeil leidt tot vermindering van de $\mathrm{CO}_{2}$-emissie als gevolg van veenoxidatie. De in tabel 3.4 getoonde emissies betreffen alleen de $\mathrm{CO}_{2}$ besparing. Effecten op de emissies van andere broeikasgassen zoals methaan en lachgas zijn buiten beschouwing gelaten omdat gegevens hierover nauwelijks beschikbaar zijn. Indirecte effecten, zoals emissies als gevolg van extra voertransporten en emissies bij de kunstmestproductie zijn wel meegenomen maar deze zijn verwaarloosbaar in vergelijking met de emissie als gevolg van veenoxidatie. Een peilverhoging van $20 \mathrm{~cm}$ bespaart een uitstoot van circa $8.100 \mathrm{~kg} \mathrm{CO} 2$ per ha. De kosten voor deze besparing zijn afhankelijk van de uitgangssituatie en bedragen gemiddeld 41 euro/ha. 
Tabel 3.4 Effect op $\mathrm{CO}_{2}$-emissie en geschatte meerkosten uitgedrukt per ton $\mathrm{CO}_{2}$-besparing bij vermindering van de drooglegging met $20 \mathrm{~cm}$ op veengrond in het Groene Hart onder verschillende uitgangssituaties

\begin{tabular}{lcccccc} 
& $100 \mathrm{~cm} \rightarrow$ & $80 \mathrm{~cm} \rightarrow$ & $60 \mathrm{~cm} \rightarrow$ & $40 \mathrm{~cm} \rightarrow$ & $30 \mathrm{~cm} \rightarrow$ & Totaal \\
& $80 \mathrm{~cm}$ & $60 \mathrm{~cm}$ & $40 \mathrm{~cm}$ & $20 \mathrm{~cm}$ & $10 \mathrm{~cm}$ \\
\hline Aandeel van slootpeilen in het Groene Hart & $12 \%$ & $10 \%$ & $28 \%$ & $43 \%$ & $7 \%$ & $100 \%$ \\
\hline Effect op $\mathrm{CO}_{2}$-emissie $(1.000 \mathrm{~kg} / \mathrm{ha})$ & $-8,0$ & $-8,0$ & $-8,0$ & $-8,1$ & $-8,2$ & $-8,1$ \\
\hline Kosteneffect (euro/ha) & 0 & 87 & 312 & 470 & 489 & 332 \\
\hline Kosteneffect (euro/ton $\mathrm{CO}_{2}$-besparing) & 0 & 11 & 39 & 58 & 60 & 41 \\
\hline
\end{tabular}

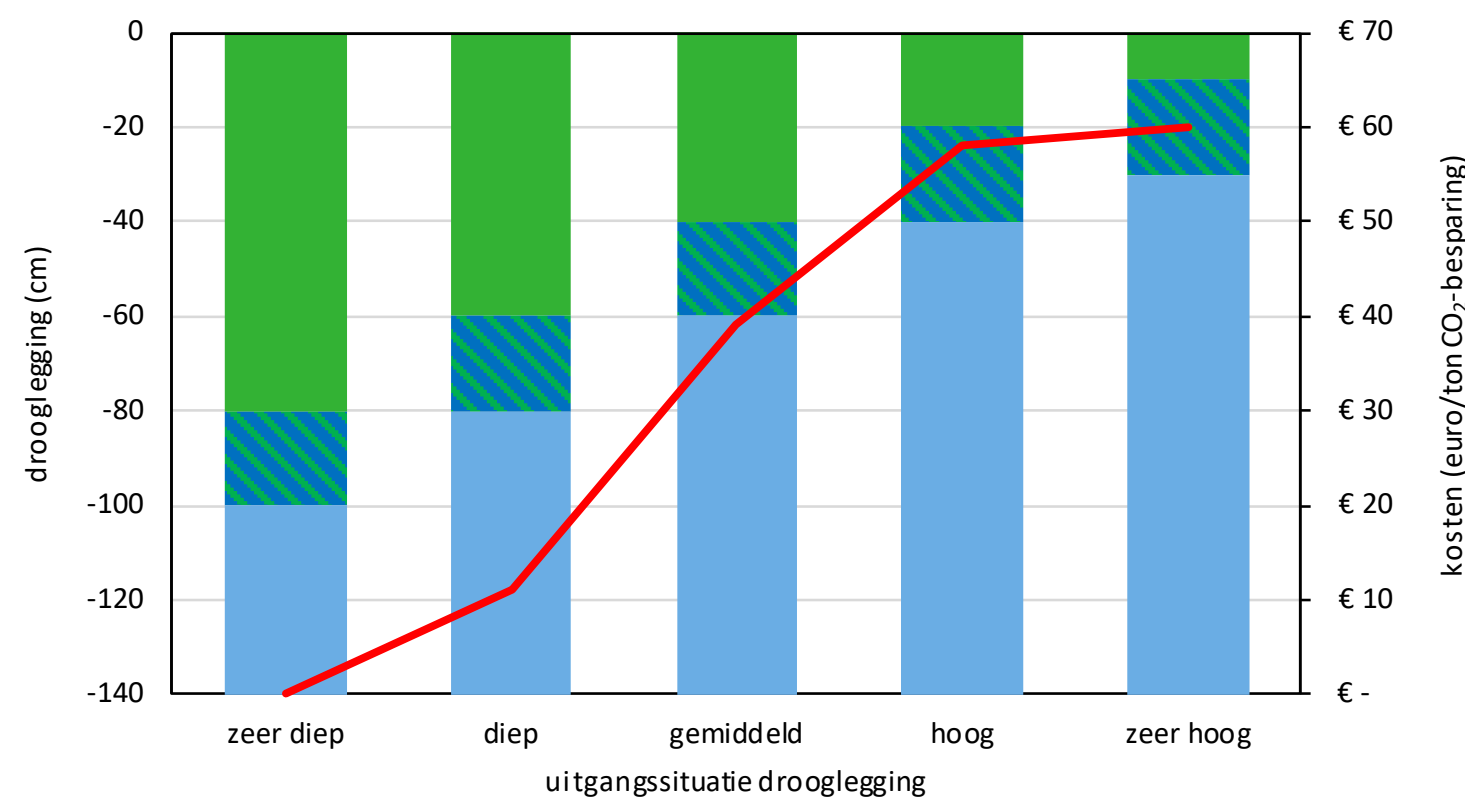

grond tot drooglegging

drooglegging in de uitgangssituatie vermindering van de drooglegging

kosten/ton $\mathrm{CO}_{2}$ besparing

Figuur 3.2 Kosten per ton besparing van $\mathrm{CO}_{2}$-emissie bij een verminderde drooglegging van $20 \mathrm{~cm}$ onder verschillende uitgangssituaties

Figuur 3.2 geeft het verband tussen de peilverhoging van $20 \mathrm{~cm}$ bij verschillende uitgangssituaties en de kosten per ton $\mathrm{CO}_{2}$-besparing grafisch weer. De kosten zijn verwaarloosbaar bij een zeer diepe waterstand, maar deze lopen op tot 60 euro per ton besparing van $\mathrm{CO}_{2}$-emissie bij een zeer hoge waterstand. 


\section{$4 \quad$ Conclusies en discussie}

\subsection{Kostprijs melk}

- De melkveebedrijven in het Groene Hart zijn gemiddeld kleiner en extensiever dan de melkveebedrijven op klei en zand en gebruiken nagenoeg alle grond als grasland.

- De melkveebedrijven in het Groene Hart scoren qua kostprijs en opbrengstprijs van melk vrijwel hetzelfde als de melkveebedrijven op klei en zand. De verschillen zijn minder dan 0,5\%.

- Het gemiddelde inkomen uit de melkveehouderij (waarbij niet de eigen arbeid in rekening wordt gebracht) in het Groene Hart is hoger dan bij de melkveebedrijven op klei en zand.

- Andere inkomsten uit het bedrijf plus het inkomen van arbeid buiten het bedrijf samen zijn in het Groene Hart iets lager dan bij de melkveebedrijven op klei en zand. Ten opzichte van de melkveebedrijven op klei en zand komen dan ook geen duidelijke compensatiestrategieën naar voren waarmee het Groene Hart 'compenseert'.

- De Nederlandse melkveebedrijven, ook die in het Groene Hart, hebben een hogere kostprijs van de melk dan melkveebedrijven in Ierland en Denemarken. Dit wordt enigszins gecompenseerd door een hogere melkprijs. De Ierse en Deense melkveebedrijven halen overigens hogere opbrengsten uit onder andere verkoop van vee.

- Al met al is de positie van de melkveehouderij in het Groene Hart in vergelijking met de meeste andere Nederlandse melkveebedrijven niet slecht. Ten opzichte van sommige andere EU-lidstaten is de situatie wat minder gunstig.

\subsection{Effecten van vernatting op kosten, kostprijs en $\mathrm{CO}_{2}$-emissie}

- Peilverhoging heeft negatieve gevolgen voor verreweg de meeste melkveehouders in het Groen Hart.

- Gemiddeld is het negatieve financiële effect van een peilverhoging met $20 \mathrm{~cm} 332$ euro/ha. Dit hangt sterk af van de uitgangssituatie. Het effect van een peilverhoging van $100 \mathrm{~cm}$ naar $80 \mathrm{~cm}$ onder maaiveld is vrijwel nihil; voor bedrijven, die nu al te maken hebben met een hoog slootpeil, kan het financiële effect oplopen tot bijna 500 euro per ha.

- De genoemde bedragen zijn per ha en gelden voor zowel kleine als grote bedrijven. De financiële derving is daardoor onafhankelijk van de bedrijfsomvang.

- Peilverhoging werkt kostprijsverhogend. De gemiddelde kostprijs van melk zal daardoor stijgen met 2,00 tot 2,50 euro per $100 \mathrm{~kg}$ melk.

- Peilverhoging leidt tot reductie van veenoxidatie en een lagere $\mathrm{CO}_{2}$-emissie.

- De meerkosten van peilverhoging komen gemiddeld overeen met 41 euro per ton $\mathrm{CO}_{2}$. De $\mathrm{CO}_{2}$-prijs zou gemiddeld 41 euro per ton $\mathrm{CO}_{2}$ moeten bedragen om het bedrijfsresultaat niet omlaag te laten gaan in geval van aanpassing van het bedrijfsmodel als gevolg van vernatting. Op dit moment is de prijs per ton $\mathrm{CO}_{2}$ rond de 20 euro.

- Voor bedrijven, die nu te maken hebben met een slootpeil dat hoger is dan $60 \mathrm{~cm}$ onder het maaiveld, zijn de meerkosten hoger dan 41 euro per ton $\mathrm{CO}_{2}$; voor bedrijven met een dieper slootpeil zijn de kosten lager. 


\subsection{Discussie}

- De kostenefficiency van emissiereductie kan aanmerkelijk worden verbeterd door de peilverhoging af te laten hangen van het huidige peil. Er zou bijvoorbeeld gestreefd kunnen worden om alle peilen tussen (meer dan) $100 \mathrm{~cm}$ en $35 \mathrm{~cm}$ terug te brengen naar $35 \mathrm{~cm}$ en de huidige peilen tussen 0 en $35 \mathrm{~cm}$ niet verder te verhogen richting 10 of $0 \mathrm{~cm}$.

- De bedrijfseconomische kosten van een algemene peilverhoging van $20 \mathrm{~cm}$ op de veengronden in het Groene Hart bedragen 35 miljoen euro per jaar. Daarmee wordt de emissie van naar schatting 0,85 miljoen ton $\mathrm{CO}_{2}$ vermeden. Specifieke peilverhoging, waarbij de drooglegging tot maximaal $35 \mathrm{~cm}$ wordt teruggebracht, kost 29 miljoen euro en bespaart eveneens 0,85 miljoen ton $\mathrm{CO}_{2}$.

- In de studie is puur gekeken en gerekend vanuit de bestaande bedrijfsstructuur en bedrijfsvoering om de compensatie, via een $\mathrm{CO}_{2}$-prijs, voor de daling in het bedrijfsresultaat als gevolg van peilverhoging te bepalen. $\mathrm{Er}$ is geen rekening gehouden met een andere bedrijfsvoering (bijvoorbeeld een ander veeras) of andere bedrijfsopzetten zoals bijvoorbeeld beschreven in de PARK-studie (Plambeck et al., 2019). Ook is geen rekening gehouden met het opvangen van financiële verliezen door het aankopen van extra hectares grond. Beide opties kunnen manieren zijn voor melkveebedrijven om met het verlies van inkomsten als gevolg van vernatting van gronden om te gaan.

- Een alternatief voor het verstrekken van een vergoeding voor de bespaarde broeikasgasemissies kan het verlagen van de pachtprijs van grond zijn, die melkveehouders in het Groene Hart momenteel van natuurorganisaties pachten. Ook zouden melkveehouders, die voor vernatting kiezen, extra grond van natuurorganisaties kunnen pachten tegen een aangepaste prijs: hectares in vernatte toestand zijn namelijk minder aantrekkelijk voor een melkveehouder dan wanneer de grond niet is vernat (voor dit principe van natuurpacht, zie De Koeijer et al., 2018). Gezien de beperkte hoeveelheid pachtgrond in relatie tot de grond in eigendom van melkveehouders lijkt dit een beperkt toepasbaar alternatief. 


\section{Literatuur en websites}

BAL (2018). What is the cost of producing milk? Gleichen, Germany: Büro für Agrarsoziologie und Landwirtschaft.

Deltares (2020) Persoonlijke mededeling bij monde van G. Erkens.

EU (2018). EU Dairy farms report based on 2016 FADN data. Brussels: European Union.

Ge, L., R.W. van der Meer, H.B. van der Veen en H.C.J. Vrolijk (2018). Sample of Dutch FADN 2015; Design principles and quality of the sample of agricultural and horticultural holdings. Wageningen, Wageningen Economic Research, Report 2018-011.

Koeijer, T. de, P.W. Blokland, E. Bos, A. Greijdanus en M.J. Smits (2018). Verkenning potentiële bijdrage pacht natuurgrasland aan natuurinclusieve landbouw: een modelmatige bedrijfseconomische analyse. Wageningen, Wageningen Economic Research, Rapport 2018-058.

Plambeck, P. (projectleider) (2019). Groene Hart; ontwerpend onderzoek naar een adaptief en gedifferentieerd landschap met de bodem als conditie, het watersysteem als instrument en het landgebruik als resultante. Den Haag, Bureau Sant en Co.

Prins, H., G. Holshof, I. Hoving, T. Vogelzang en N. Polman (2018). Peilverhoging op veenweidegronden; effecten van peilverhoging op broeikasgasemissies en financiële resultaten. Wageningen Economic Research, Notitie (op verzoek te verkrijgen bij de auteurs).

Teagasc (2018). Teagasc National Farm Survey 2017, Dairy Enterprise Factsheet. Galway, Ireland: Teagasc Agricultural Economics and Farm Surveys Department.

Teagasc (2019). Teagasc National Farm Survey 2018, Dairy Enterprise Factsheet. Galway, Ireland: Teagasc Agricultural Economics and Farm Surveys Department.

Website Agrimatie http://www.agrimatie.nl

Website FADN Public Database https://ec.europa.eu/agriculture/rica/database/database_en.cfm 
Wageningen Economic Research Postbus 29703

2502 LS Den Haag

T 0703358330

Ecommunications.ssg@wur.nl

www.wur.nl/economic-research

Wageningen Economic Research RAPPORT

2020-017c
De missie van Wageningen University \& Research is 'To explore the potential of nature to improve the quality of life'. Binnen Wageningen University \& Research bundelen Wageningen University en gespecialiseerde onderzoeksinstituten van Stichting Wageningen Research hun krachten om bij te dragen aan de oplossing van belangrijke vragen in het domein van gezonde voeding en leefomgeving. Met ongeveer 30 vestigingen, 5.000 medewerkers en 12.000 studenten behoort Wageningen University \& Research wereldwijd tot de aansprekende kennisinstellingen binnen haar domein. De integrale benadering van de vraagstukken en de samenwerking tussen verschillende disciplines vormen het hart van de unieke Wageningen aanpak. 



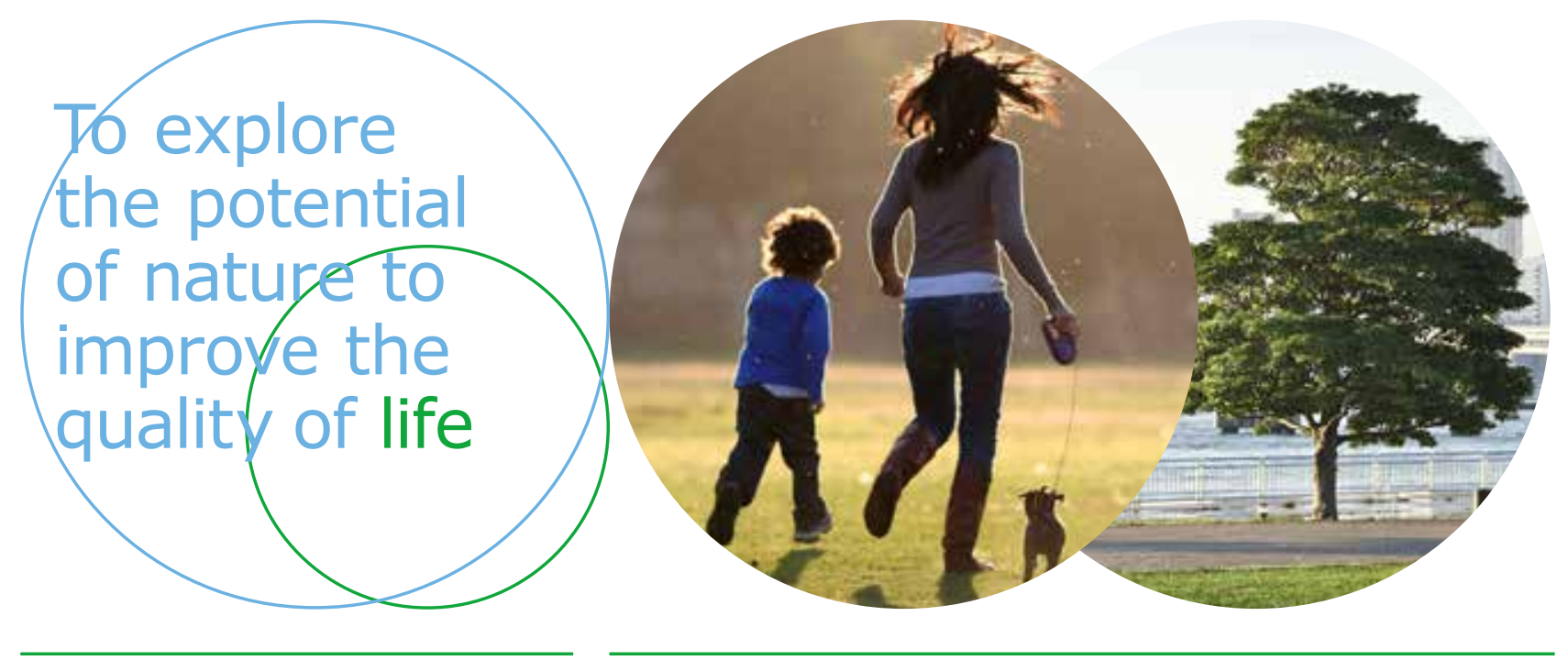

Wageningen Economic Research Postbus 29703

2502 LS Den Haag

T 0703358330

E communications.ssg@wur.nl www.wur.nl/economic-research

Rapport 2020-017c

ISBN 978-94-6395-407-5
De missie van Wageningen University \& Research is 'To explore the potential of nature to improve the quality of life'. Binnen Wageningen University \& Research bundelen Wageningen University en gespecialiseerde onderzoeksinstituten van Stichting Wageningen Research hun krachten om bij te dragen aan de oplossing van belangrijke vragen in het domein van gezonde voeding en leefomgeving. Met ongeveer 30 vestigingen, 5.000 medewerkers en 12.000 studenten behoort Wageningen University \& Research wereldwijd tot de aansprekende kennisinstellingen binnen haar domein. De integrale benadering van de vraagstukken en de samenwerking tussen verschillende disciplines vormen het hart van de unieke Wageningen aanpak. 